\title{
Grey Relational Optimization of Turning Parameters in Dry Machining of Austenitic Stainless Steel Using Zr Based Coated Tools
}

\author{
Kaushik Vijaya Prasad, Kishore Triambak Kashyap, Madapat Job Richard, \\ Posina Gerard Prabhu Rao, Abhishek Rajole, Rabara Hiren \\ Department of Mechanical Engineering, School of Engineering \& Technology, Jain University, Karnataka, India \\ Email: ka ushikvijayprasad@gmail.com
}

How to cite this paper: Prasad, K.V., Kashyap, K.T., Richard, M.J., Rao, P.G.P., Rajole, A. and Hiren, R. (2017) Grey Relational Optimization of Turning Parameters in Dry Machining of Austenitic Stainless Steel Using Zr Based Coated Tools. Open Journal of Applied Sciences, 7, 337-347. https://doi.org/10.4236/ojapps.2017.77027

Received: May 14, 2017

Accepted: July 11, 2017

Published: July 14, 2017

Copyright $\odot 2017$ by authors and Scientific Research Publishing Inc. This work is licensed under the Creative Commons Attribution International License (CC BY 4.0).

http://creativecommons.org/licenses/by/4.0/

\begin{abstract}
The present work aims at the microstructural characterization of TiAlZrN/ $\mathrm{Al}_{2} \mathrm{O}_{3}$ and TiAlZrN/Si ${ }_{3} \mathrm{~N}_{4}$ coatings deposited via lateral rotating cathodes. The coatings were deposited using Lateral Rotating Cathodes (LARC) technology. The deposited coatings were studied for its cross sectional morphology using scanning electron microscopy. Energy Dispersive Spectrometry was also conducted along the cross section to determine the elemental composition. Micro Vickers hardness test was conducted to determine the hardness of the coatings. The scanning electron microscope images showed that TiAlZrN/ $/ \mathrm{Al}_{2} \mathrm{O}_{3}$ coatings showed preferred columnar grain orientation with multilayered structure while TiAlZrN $/ \mathrm{Si}_{3} \mathrm{~N}_{4}$ coatings exhibit a dense grain structure. The TiAlZrN/Si $\mathrm{N}_{4}$ coating shows a hardness of $31.58 \mathrm{GPa}$ while TiAlZrN/Al $/ \mathrm{O}_{3}$ coating shows a hardness of $25.40 \mathrm{GPa}$. Dry turning tests were performed on AISI 304 stainless steel. The TiAlZrN/Si ${ }_{3} \mathrm{~N}_{4}$ coatings show reduced flank wear. Both the coatings even under severe cutting conditions impart surface roughness of less than $1.5 \mu \mathrm{m}$.
\end{abstract}

\section{Keywords}

Coatings, Lateral Rotating Cathodes, Dry Machining, High Speed Machining, Coated Cutting Tools, Flank Wear, Dry Turning

\section{Introduction}

High productivity, good finished products and reducing manufacturing costs are major challenges to present metal working industries. High speed machining is seen as a promising solution to these challenges. However the process of machining involves relative motion between the work piece and cutting tool which 
gives rise to generation of heat at the contact zone due to friction. Cutting fluids or coolants is used to reduce the temperature at the point of contact, facilitate the flow of chips and prevent the adhesion between work piece and tool. The coolants or cutting fluids pose several problems to the environment and the personnel operating the machine. Further, the cost of the coolant sums up to nearly $15 \%-30 \%$ of the total machining cost [1] [2]. These factors have prompted the industries to adopt the concept of near dry machining which is also called as "Minimal Quantity Lubrication" (MQL) or "Extremely Low Quantity of Lubricant" machining. In this technique, the coolant used will be less than $100 \mathrm{ml} / \mathrm{h}$ [3]. Chinchanikar et al. [4] performed hard turning on AISI 4340 steel using nano structured AlTiN, multi-layered TiAlN/TiSiN and AlTiCrN coated tools under dry and MQL cutting conditions. It was found that MQL conditions offered higher tool life. Higher tool life was observed in case of nanocrystalline AlTiCrN coated inserts. Similarly Derflinger et al. [5] suggests the use of a hard coating with lubricating layer to increase life time of cutting tool under MQL conditions. But still near dry machining is yet to gain popularity because of factors such as cost involved, removal of chips and overall reliability of the system. In addition it has been reported that most of the cutting fluids are nonbiodegradable in nature [6]. In view of these factors, dry machining gains its importance in metal working industries. But it also imposes a challenge for the requirement of cutting tool which possesses high thermal stability and wear resistance. The most suited cutting tool for such applications is to use cemented carbide inserts of K25 grade with WC-Co composition. But these inserts give a poor and erratic surface finish when used to machine the stainless steel alloys at high speeds [7] [8]. Austenitic stainless steel is one such material and has been categorized as one among "difficult-to-cut" material. This grade of steel finds its applications in chemical and food processing equipments and machine parts which require high corrosion resistance. High tool wear, low thermal conductivity, high work hardening effect and rough surface finish are some of the common problems associated in machining this grade of stainless steel [9]. In order to overcome these issues the coated cemented carbide inserts are used. The coatings belonging to the TiAlN family have gained significant attention in this regard and several works have been carried out to demonstrate their high temperature behaviour. Settineri et al. [10] used AlSiTiN and AlSiCrN to perform dry milling on AISI M2 steel at speed of $150 \mathrm{~m} / \mathrm{min}$. and feed of $0.050 \mathrm{~mm} / \mathrm{rev}$./tooth. It was found that $\mathrm{AlSiCrN}$ tool showed less resistance. Abia et al. [11] performed dry turning on AISI 304 stainless steel using various coated tools such as AlTiSiN, AlCrSiN and TiAlN. It was observed in their studies that AlTiSiN coated tools showed significantly less wear on comparison with the others. Even under the most severe cutting conditions the roughness imparted to work parts was less than $2 \mu \mathrm{m}$. Similar results were found by Kaushik et al. [12] in their work. Studies show that Ti-Al-M-N ( $\mathrm{M}$ = transition metal) systems have been investigated widely; while very few studies have been carried out on $\mathrm{Zr}$ based coatings. It is well established that $\mathrm{ZrN}$ has lower coefficient of friction and higher hardness compared to TiN. 
However its poor oxidation resistance limits its applications. Hence alloying $\mathrm{Zr}$ with other transition metal nitrides improves its thermal and mechanical properties significantly [13] [14] [15]. While bulk efforts have been made to understand the high temperature behaviour of these systems, there are very scarce amount of work reports on its applications such as turning, milling etc.

Hence the present work aims on the optimization of cutting parameters using Grey Relation Analysis (GRA) in dry turning of AISI 304 stainless steel using TiAlZrN/Si ${ }_{3} \mathrm{~N}_{4}$ and TiAlZrN/ $/ \mathrm{Al}_{2} \mathrm{O}_{3}$ coated cemented carbide inserts.

\section{Experimental Details}

\subsection{Coating Deposition Technique}

The coatings were deposited by means of Cathodic Arc Evaporation (CAE) which is a physical vapor deposition (PVD) technique using Hind High Vacuum industrial coating unit. The coating unit consisted of two lateral rotating cathodes mounted on the door of the chamber with the magnetic filters. The entire coating process is controlled by computer to monitor the deposition rates, thickness, cycle times etc. The targets used were 99\% pure. TNMG160404 inserts of cemented carbide (WC-Co) K25 grade were used as the substrate material. The inserts were cleaned with acetone and de-ionized water to remove impurities and contaminants and blow dried in nitrogen atmosphere at $100^{\circ} \mathrm{C}$. The inserts were placed on the carousel and the substrate was biased at $-85 \mathrm{~V}$, the targets were biased at $-17 \mathrm{~V}$ and the current varied between $80-120 \mathrm{~A}$ to modulate the ratio of various elements. The equipment is controlled by PLC to optimize and deposit the required thickness of coating of about $10 \pm 4 \mu \mathrm{m}$. The target size was $50 \mathrm{~mm}$ in diameter and length of $510 \mathrm{~mm}$. Nitrogen gas was supplied to the vacuum chamber at a pressure of 1.5 Pa. Further details of the deposition method are described in our previous work [12].

\subsection{Micro Hardness Test and Scanning Electron Microscopy}

Vickers micro-hardness test was conducted on the as deposited coatings, using Matsuzawa MMTX7 automated hardness tester. A load of $100 \mathrm{gmf}$ was used to indent the specimen. The dwell time was 20 seconds and a diamond pyramid indenter was used to calculate the hardness. Scanning electron micrographs were obtained for the fractured samples of the coatings using Jeol JSM7100FT field emission scanning electron microscope. An acceleration voltage of $30 \mathrm{kV}$ was used during the process. The equipment was attached with the Energy Dispersive Spectrometry (EDS) facility and the elemental compositions in the coatings at different regions were found from the EDS. The take-off angle was $30^{\circ}$ and 200 seconds of scan were made on samples for identifying the elemental composition.

\subsection{Cutting Tests and Flank Wear Determination}

Dry turning was performed using ACE CNC Jobber XL. AISI 304 stainless steel was chosen as the work material. The work piece had a diameter of $50 \mathrm{~mm}$ and 
length of $300 \mathrm{~mm}$ respectively. The speed, feed and depth of cut were chosen as per the Taguchi's L8 orthogonal array. The cutting parameters are as shown in Table 1 and Taguchi's L8 orthogonal array is shown in Table 2.

The wear was determined using confocal laser microscopy and surface roughness of the finished work parts were found using Mitutoyo SJ 201 surface roughness tester.

\section{Results and Discussions}

\subsection{Characterization of Coatings}

The hardness of the coating is observed to be higher than that of the substrate. The substrate has got hardness of $1755 \mathrm{HV}$ whereas the coating has got hardness as shown in Table 3. The hardness of the deposited coatings increases due to solid solution strengthening, high dislocation density and fine grain size. The coating is a polycrystalline array with fine grain size. Further the hardness of coating is much higher compared to the work piece hardness ( 92 HRB) hence making it suitable for hard turning [16] [17] [18].

Figure 1 shows the scanning electron micrographs of the investigated coatings. The TiAlZrN/ $/ \mathrm{Al}_{2} \mathrm{O}_{3}$ coatings show bilayer structure.

Table 1. Values of the cutting parameters chosen for dry turning test.

\begin{tabular}{ccc}
\hline \multirow{2}{*}{ Sl.No } & \multicolumn{2}{c}{ Values for cutting parameters for dry turning test } \\
\cline { 2 - 3 } & Parameters & Values \\
\hline 1. & Speed $(\mathrm{m} / \mathrm{min})$. & $200,220,240,260$ \\
2. & Feed rate $(\mathrm{mm} / \mathrm{rev})$. & $0.1,0.3$ \\
3. & Depth of Cut $(\mathrm{mm})$ & 1 \\
\hline
\end{tabular}

Table 2. Taguchi's L8 Orthogonal Array.

\begin{tabular}{cc}
\hline \multicolumn{3}{c}{ Taguchi's L8 Array } \\
\hline Speed (m/min.) & Feed Rate (mm/rev.) \\
\hline 200 & 0.1 \\
200 & 0.3 \\
220 & 0.1 \\
220 & 0.3 \\
240 & 0.1 \\
240 & 0.3 \\
260 & 0.1 \\
260 & 0.3 \\
\hline
\end{tabular}

Table 3. Micro Vickers hardness of coatings.

\begin{tabular}{cccc}
\hline S1. No. & Coating Type & Hardness HV0.1 & Hardness (GPa) \\
\hline 1. & $\mathrm{TiAlZrN} / \mathrm{Al}_{2} \mathrm{O}_{3}$ & 2590 & 25.4 \\
2. & $\mathrm{TiAlZrN} / \mathrm{Si}_{3} \mathrm{~N}_{4}$ & 3250 & 31.58 \\
\hline
\end{tabular}



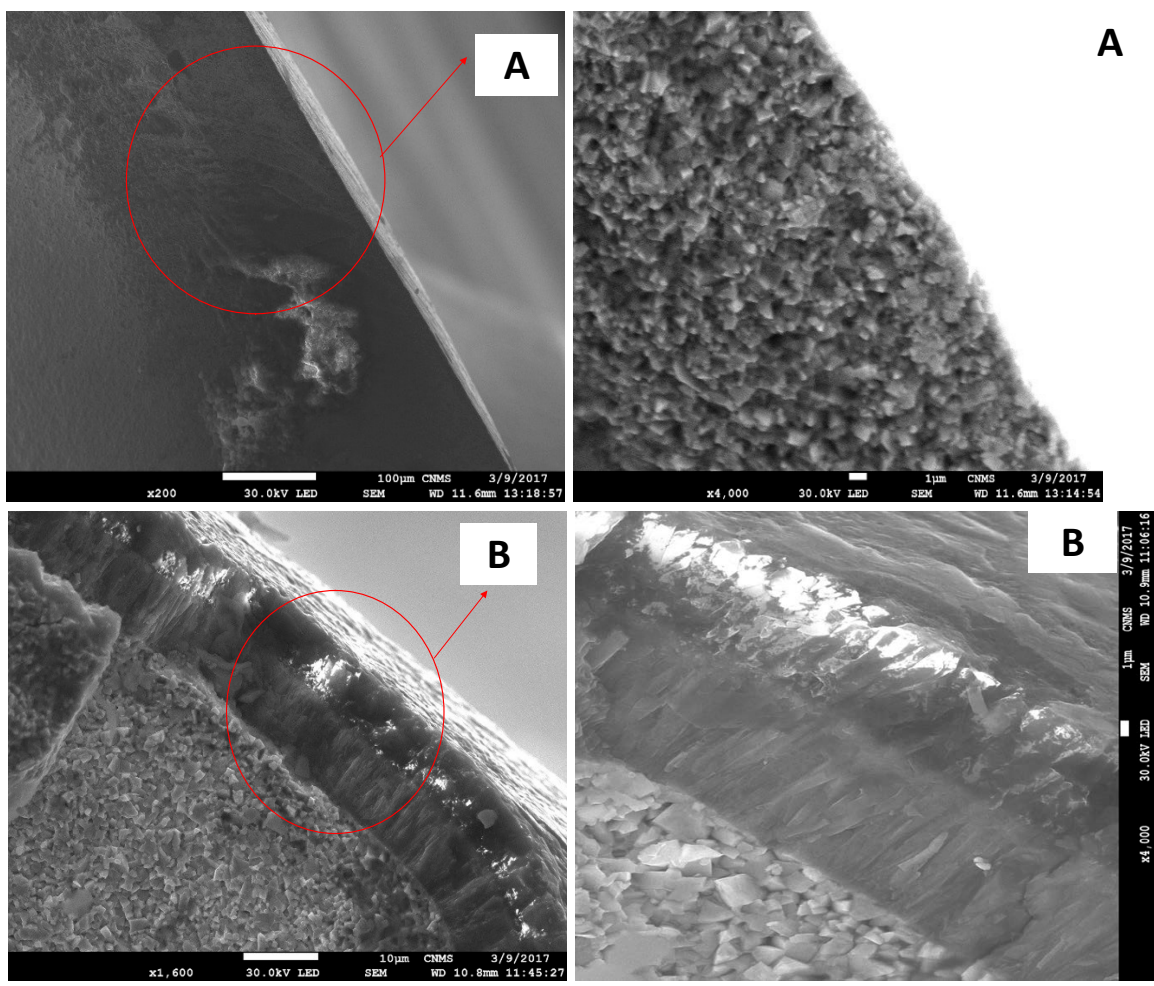

Figure 1. SEM of cross section of fractured samples of coatings: (A) TiAlZrN/ $\mathrm{Al}_{2} \mathrm{O}_{3}$; (B) $\mathrm{TiAlZrN} / \mathrm{Si}_{3} \mathrm{~N}_{4}$ with their magnified views.

The TiAlZrN/ $/ \mathrm{Al}_{2} \mathrm{O}_{3}$ coating shows a columnar grain structure with preferred orientation. The coating is uniform without any delamination from the substrate. While the TiAlZrN/Si ${ }_{3} \mathrm{~N}_{4}$ coating show an equiaxed grain structure with reduced columnar orientation. The reduction in columnar grain structure is due to the spinodal phase segregation mechanism. Spinodal decomposition is due to composition fluctuations leading to modulations. The modulations lead to lean in solute regions and rich in solute regions. The diffusion coefficients are negative leading to uphill diffusion in the modulations. The coating segregates into a crystalline TiAlZrN grains and amorphous $\mathrm{Si}_{3} \mathrm{~N}_{4}$ phase. This segregation of phase promotes fine grain structure. The increase in hardness of the TiAlZrN/ $\mathrm{Si}_{3} \mathrm{~N}_{4}$ coating compared to TiAlZrN/Al $\mathrm{O}_{3}$ coatings can be attributed to this factor. The columnar orientation reduces the hardness of the coating and facilitates higher rate of heat transfer [19] [20].

Energy Dispersive Spectrometry (EDS) was performed along the cross section of the coatings to determine the elements present. Figure 2 shows the EDS spectra for both the coatings along with their compositions.

From the EDS spectra it is evident that the TiAlZrN/Si $\mathrm{N}_{4}$ coatings showed the presence of oxygen at about $7 \%$. This presence of oxygen could be due to low nitrogen activity. Further presence of oxygen above 3\% can reduce the hardness of the coatings. This factor contributes to the fact that the coating did not reach the super hardness state of above $35 \mathrm{GPa}$. In the EDS spectrum of TiAlZrN/ $/ \mathrm{Al}_{2} \mathrm{O}_{3}$ the matrix peaks are also visible thus showing that the coating thickness is small at the fracted region [1]. 


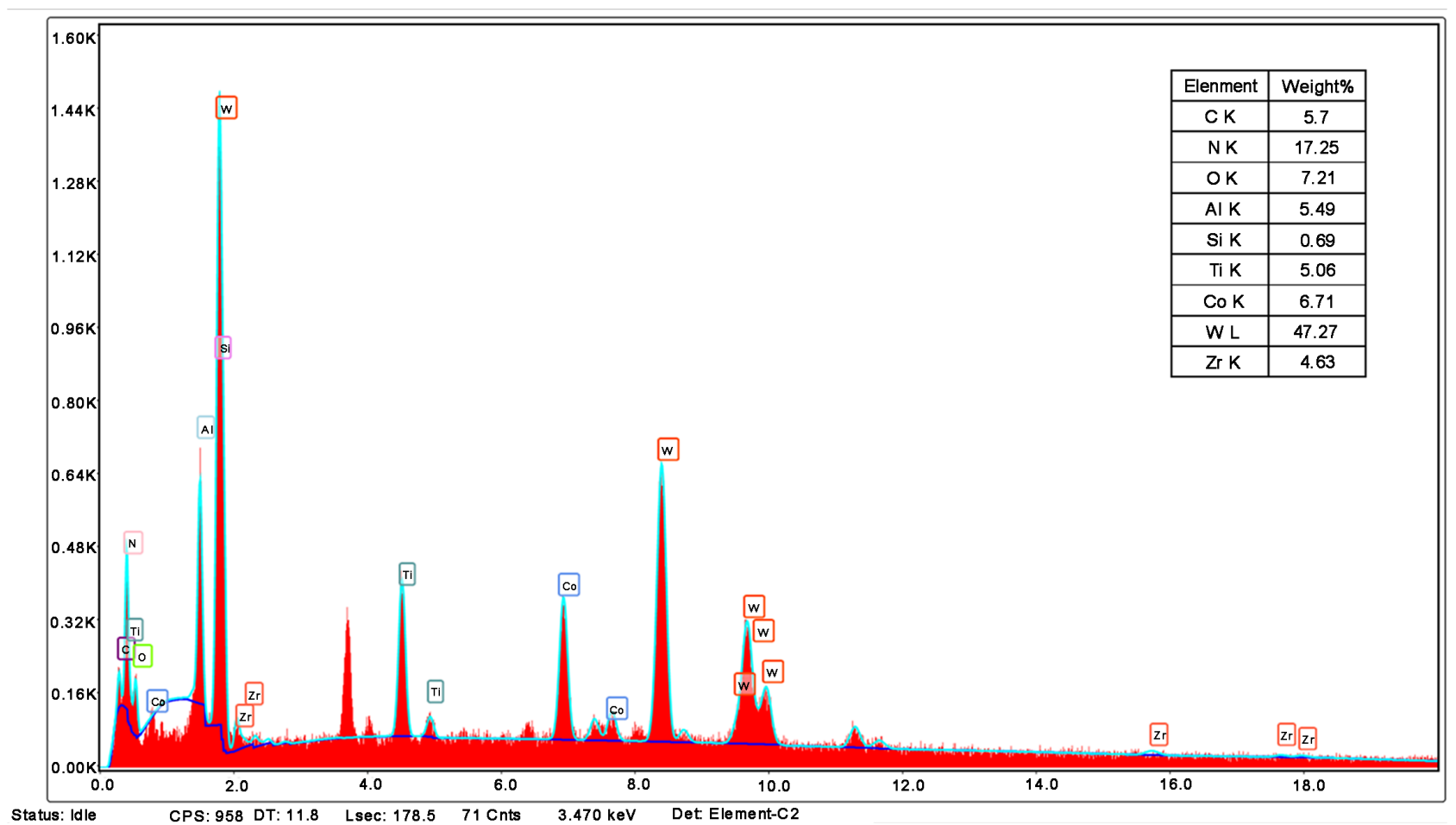

(A)

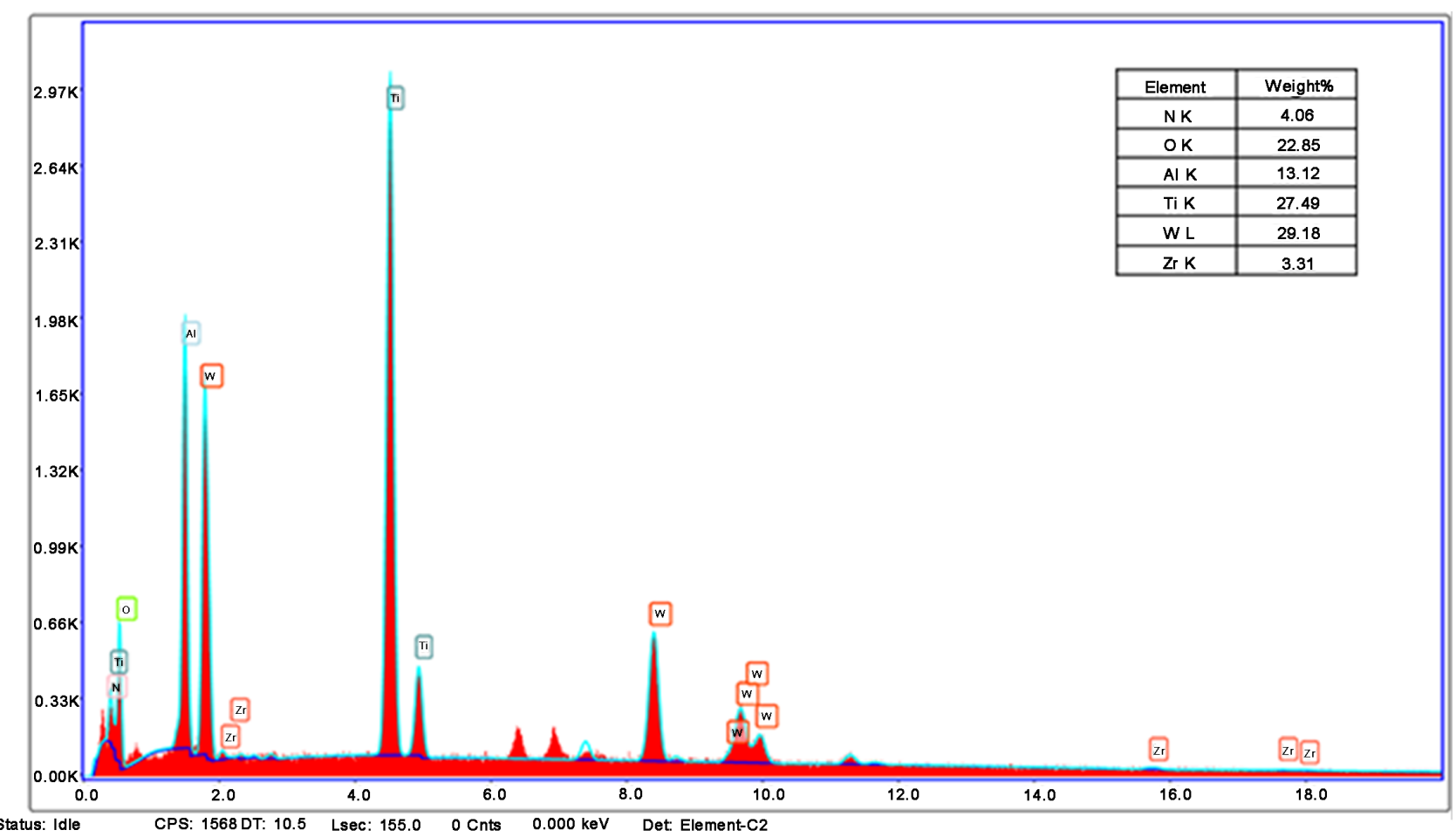

(B)

Figure 2. EDS spectra of (A) TiAlZrN/Si ${ }_{3} \mathrm{~N}_{4}$; (B) TiAlZrN/Al ${ }_{2} \mathrm{O}_{3}$ coatings.

\subsection{Cutting Test and Grey Relational Optimization of Cutting Parameters}

The cutting tests were carried out using ACE CNC Jobber XL machine. Ten minutes of uninterrupted continuous dry turning was performed on AISI 304 
stainless steel. The flank wear then was determined using confocal laser microscope. The wear images for different coated inserts are shown in Figure 3.

The wear in TiAlZrN/Si ${ }_{3} \mathrm{~N}_{4}$ coated inserts was less compared to the TiAlZrN/ $\mathrm{Al}_{2} \mathrm{O}_{3}$ coated inserts. The wear in TiAlZrN/Si ${ }_{3} \mathrm{~N}_{4}$ coatings was mainly due to abrasion. Some built up edges were observed. This shows the coating exhibits good thermal stability at high temperatures under assumed cutting test conditions. The TiAlZrN/ $/ \mathrm{Al}_{2} \mathrm{O}_{3}$ coatings show higher wear compared to the former coatings. The wear here is mainly due to abrasion and chipping at the flank and nose of the cutting tool. Notch wear is also seen prominently in this coated tool. Both the tools did not exhibit any significant crater wear. The possible reason for the higher wear in TiAlZrN/ $/ \mathrm{Al}_{2} \mathrm{O}_{3}$ tools is due to propagation of cracks in transverse direction due to columnar grain structure. The TiAlZrN/Si $\mathrm{N}_{4}$, due to their dense grain structure, exhibits better wear resistance. The crack propagations are hindered in the dense grains [21] [22].

\subsection{Grey Relational Analysis}

Grey Relational Analysis (GRA) is performed to convert a multi-objective problem into a single objective optimization. In the present work we need both the flank wear and surface roughness to be low hence it becomes a multi-objective problem. The first stage in GRA involves the normalization of data between 0 and 1 . It is carried out using the equation given below:
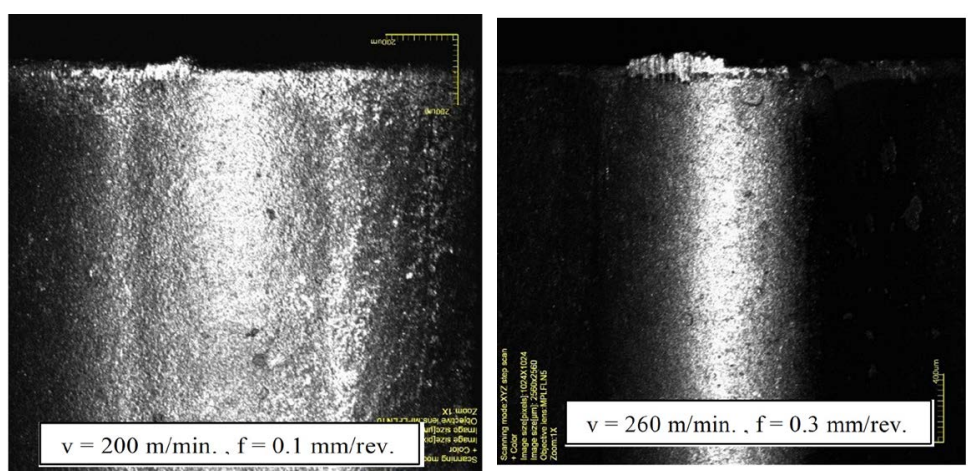

(A)
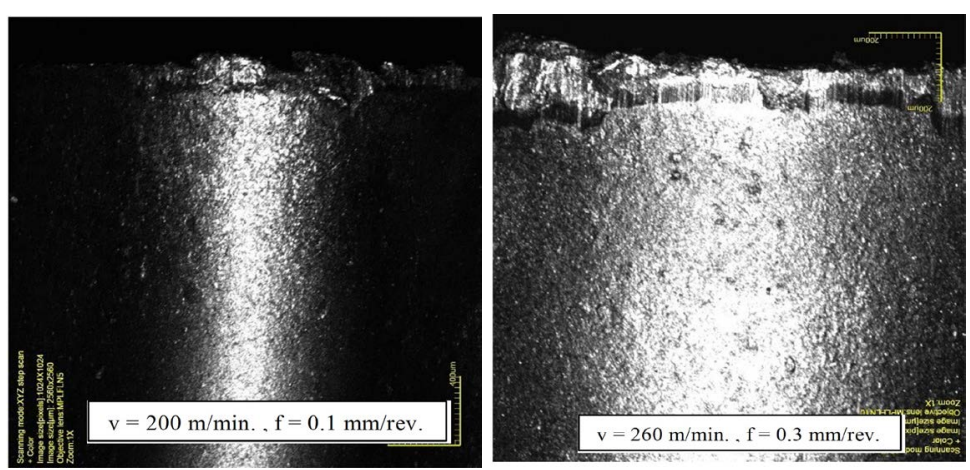

(B)

Figure 3. Confocal laser microscopy images of flank wear of (A) $\mathrm{TiAlZrN} / \mathrm{Si}_{3} \mathrm{~N}_{4}$; (B) TiAlZrN/ $\mathrm{Al}_{2} \mathrm{O}_{3}$ inserts. 


$$
X_{i} *(k)=\frac{X_{i \operatorname{Max}}-X_{i}(k)}{X_{i \operatorname{Max}}(k)-X_{i}(k)}
$$

where $X_{i}^{*}(k)$ and $X_{i}(k)$ are normalized and observed data respectively. After carrying out the normalization for each response grey relation coefficient is calculated for each response using the Equation (2)

$$
\zeta_{i}(k)=\frac{\Delta_{\min }+\zeta \Delta_{\max }}{\Delta_{i}(k)+\zeta \Delta_{\max }}
$$

where $\Delta_{i}=1-X_{i}(k)$ and $\zeta=0.5$ Further, the grey relation grade is found using $\Upsilon_{i}=1 / m \sum w X_{i} \zeta_{i}(k)$ where $w=1$ and $m=$ no. of trials taken $=8$. The highest grade gives optimum flank wear and surface roughness of the work part. Table 4 shows the GRA analysis for TiAlZrN/Si ${ }_{3} \mathrm{~N}_{4}$ and $\mathrm{TiAlZrN} / \mathrm{Al}_{2} \mathrm{O}_{3}$ coated tools.

It was observed that $\mathrm{TiAlZrN} / \mathrm{Al}_{2} \mathrm{O}_{3}$ exhibited higher flank wear on comparison with $\mathrm{TiAlZrN} / \mathrm{Si}_{3} \mathrm{~N}_{4}$ coatings. This higher wear rate could be due to fragile behaviour of the $\mathrm{Al}_{2} \mathrm{O}_{3}$ layer which tends to be brittle [22] [23]. It is clear from the GRA table that as the speed increases the roughness imparted to work piece

Table 4. GRA for TiAlZrN/Si ${ }_{3} \mathrm{~N}_{4}$ coated inserts.

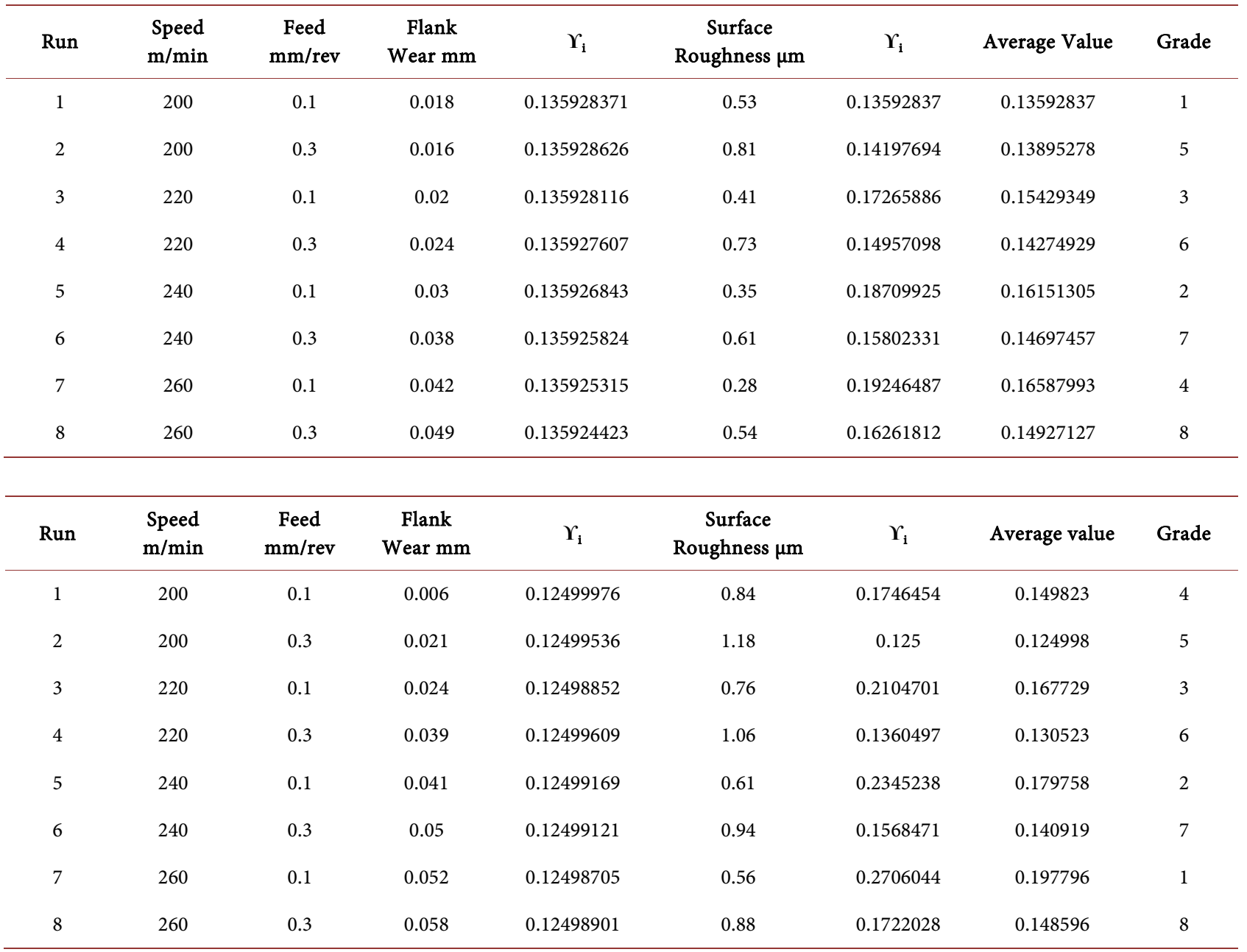


decreases also higher speed and feed promotes higher flank wear. This is in good agreement with classical metal cutting theory. A speed of $200 \mathrm{~m} / \mathrm{min}$. and feed rate of $0.1 \mathrm{~mm} / \mathrm{rev}$. produces an optimum flank wear and surface finish in case of TiAlZrN/Si ${ }_{3} \mathrm{~N}_{4}$ coated insert while a speed of $260 \mathrm{~m} / \mathrm{min}$. and a feed of 0.1 $\mathrm{mm} / \mathrm{rev}$. is suited for TiAlZrN/ $/ \mathrm{Al}_{2} \mathrm{O}_{3}$ coated inserts. In either case low feed produces optimum quality. This is because with increase in feed rate will have an increase in radial component of cutting force hence giving rise to erratic surface finish and flank wear. In our previous work similar cutting tests were carried out using the AlTiN/Si $\mathrm{N}_{4}$ coated inserts. The flank wear and surface roughness was much higher compared to the present findings. This validates that incorporation of $\mathrm{Zr}$ into the ternary coatings proves beneficial for dry cutting applications.

\section{Conclusion}

The coatings TiAlZrN/Si ${ }_{3} \mathrm{~N}_{4}$ and TiAlZrN/ $/ \mathrm{Al}_{2} \mathrm{O}_{3}$ were deposited using physical vapor deposition technique. The coatings were investigated for its structural properties. The TiAlZrN/Si $\mathrm{N}_{4}$ coatings exhibited a microhardness of $31.58 \mathrm{GPa}$ which was higher than that of TiAlZrN/ $/ \mathrm{Al}_{2} \mathrm{O}_{3}$ coating. The cross sectional morphology of the coatings was studied using scanning electron microscope. Equiaxed dense grain structure with reduced columnar orientation was found in case of TiAlZrN/Si ${ }_{3} \mathrm{~N}_{4}$ coatings. Cutting tests show that even under the severe conditions of speed and feed rates both the coatings impart a good surface finish to work piece. The roughness is well below $1.5 \mu \mathrm{m}$ in all the cases. However TiAlZrN $/ \mathrm{Si}_{3} \mathrm{~N}_{4}$ coatings show lower flank wear which is attributed to its good hot hardness and dense equiaxed grain structure. Further modifications in the tool geometry open a greater advancement for the performance of these tools in high speed dry machining.

\section{References}

[1] Veprek, S. and Veprek-Heijman, M.J. (2008) Industrial Applications of Superhard Nanocomposite Coatings. Surface and Coatings Technology, 202, 5063-5073. https://doi.org/10.1016/j.surfcoat.2008.05.038

[2] Sivarajan, S. and Padmanabhan, R. (2014) Green Machining and Forming by the Use of Surface Coated Tools. Procedia Engineering, 97, 15-21. https://doi.org/10.1016/j.proeng.2014.12.219

[3] Li, K.M. and Liang, S.Y. (2006) Modeling of Cutting Temperature in Near Dry Machining. Journal of Manufacturing Science and Engineering, 128, 416-424. https://doi.org/10.1115/1.2162907

[4] Chinchanikar, S. and Choudhury, S.K. (2014) Hard Turning Using HiPIMS-Coated Carbide Tools: Wear Behavior under Dry and Minimum Quantity Lubrication (MQL). Measurement, 55, 536-548. https://doi.org/10.1016/j.measurement.2014.06.002

[5] Derflinger, V., Brändle, H. and Zimmermann, H. (1999) New Hard/Lubricant Coating for Dry Machining. Surface and Coatings Technology, 113, 286-292. https://doi.org/10.1016/S0257-8972(99)00004-3

[6] Shokrani, A., Dhokia, V. and Newman, S.T. (2012) Environmentally Conscious Machining of Difficult-to-Machine Materials with Regard to Cutting Fluids. Interna- 
tional Journal of Machine Tools and Manufacture, 57, 83-101.

https://doi.org/10.1016/j.ijmachtools.2012.02.002

[7] Sreejith, P.S. and Ngoi, B.K. (2000) Dry Machining: Machining of the Future. Journal of Materials Processing Technology, 101, 87-91.

https://doi.org/10.1016/s0924-0136(00)00445-3

[8] Rao, P.N. (2004) CAD/CAM: Principles and Applications. Tata McGraw-Hill Education, New York City.

[9] Korkut, I., Kasap, M., Ciftci, I. and Seker, U. (2004) Determination of Optimum Cutting Parameters during Machining of AISI 304 Austenitic Stainless Steel. Materials \& Design, 25, 303-305. https://doi.org/10.1016/j.matdes.2003.10.011

[10] Settineri, L., Faga, M.G., Gautier, G. and Perucca, M. (2008) Evaluation of Wear Resistance of AlSiTiN and AlSiCrN Nanocomposite Coatings for Cutting Tools. CIRP Annals-Manufacturing Technology, 57, 575-578.

https://doi.org/10.1016/j.cirp.2008.03.103

[11] Fernández-Abia, A.I., Barreiro, J., Fernández-Larrinoa, J., de Lacalle, L.L., FernándezValdivielso, A. and Pereira, O.M. (2013) Behaviour of PVD Coatings in the Turning of Austenitic Stainless Steels. Procedia Engineering, 63, 133-141. https://doi.org/10.1016/j.proeng.2013.08.241

[12] Prasad, K.V., Pal, R. and Kuncham Rajendraprasad, V. (2016) Optimization of Cutting Parameters during Dry Turning of Austenitic Stainless Steel Using nc-AlTiN/ Si3N4, TiAlN, and TiN Coated Inserts. Journal of Materials, 2016, Article ID: 3495698. https://doi.org/10.1155/2016/3495698

[13] Rogström, L., Johansson, M.P., Ghafoor, N., Hultman, L. and Odén, M. (2012) Influence of Chemical Composition and Deposition Conditions on Microstructure Evolution during Annealing of Arc Evaporated ZrAlN Thin Films. Journal of Vacuum Science \& Technology A: Vacuum, Surfaces, and Films, 30, 031504. https://doi.org/10.1116/1.3698592

[14] Du, J., Zhu, X.Y., Cai, Z.H. and Zhang, P. (2011) Toughing of ZrAlN Film through Superlattice Design. Advanced Materials Research, 291, 141-145. https://doi.org/10.4028/www.scientific.net/AMR.291-294.141

[15] Kanoun, M.B. and Goumri-Said, S. (2014) Effect of Alloying on Elastic Properties of ZrN Based Transition Metal Nitride Alloys. Surface and Coatings Technology, 255, 140-145. https://doi.org/10.1016/j.surfcoat.2014.03.048

[16] Vepřek, S. (1999) The Search for Novel, Superhard Materials. Journal of Vacuum Science \& Technology A: Vacuum, Surfaces, and Films, 17, 2401-2420. https://doi.org/10.1116/1.581977

[17] Veprek-Heijman, M.G. (2016) Superhard and Ultrahard Nanostructured Materials and Coatings. In: Kanyanta, V., Ed., Microstructure-Property Correlations for Hard, Superhard, and Ultrahard Materials, Springer International Publishing, Berlin, 167-210.

[18] Lukazkowicz, K. (2012) Investigations of Nanocrystalline and Gradient Coatings Produced by Cathodic Arc Evaporation Technology. Journal of Achievements in Materials and Manufacturing Engineering, 52, 75-82.

[19] Samani, M.K., Ding, X.Z., Amini, S., Khosravian, N., Cheong, J.Y., Chen, G. and Tay, B.K. (2013) Thermal Conductivity of Titanium Aluminum Silicon Nitride Coatings Deposited by Lateral Rotating Cathode Arc. Thin Solid Films, 537, 108 112. https://doi.org/10.1016/j.tsf.2013.04.029

[20] Cottrell, A. (1990) An Introduction to Metallurgy. Universities Press, Belfast.

[21] Grigoriev, S.N., Vereschaka, A.A., Fyodorov, S.V., Sitnikov, N.N. and Batako, A.D. (2016) Comparative Analysis of Cutting Properties and Nature of Wear of Carbide 
Cutting Tools with Multi-Layered Nano-Structured and Gradient Coatings Produced by Using of Various Deposition Methods. The International Journal of Advanced Manufacturing Technology, 90, 3421-3435.

https://doi.org/10.1007/s00170-016-9676-Z

[22] Carvalho, S., Parreira, N.M., Silva, M.Z., Cavaleiro, A. and Rebouta, L. (2012) InService Behaviour of (Ti, Si, Al) N X Nanocomposite Films. Wear, 274, 68-74. https://doi.org/10.1016/j.wear.2011.08.018

[23] Kingery, W.D. (1977) Introduction to Ceramics. Journal of the Electrochemical Society, 124, 152C. https://doi.org/10.1149/1.2133296

Submit or recommend next manuscript to SCIRP and we will provide best service for you:

Accepting pre-submission inquiries through Email, Facebook, LinkedIn, Twitter, etc. A wide selection of journals (inclusive of 9 subjects, more than 200 journals) Providing 24-hour high-quality service User-friendly online submission system Fair and swift peer-review system Efficient typesetting and proofreading procedure Display of the result of downloads and visits, as well as the number of cited articles Maximum dissemination of your research work

Submit your manuscript at: http://papersubmission.scirp.org/ Or contact ojapps@scirp.org 